\title{
Analisis Secara Makroanatomi dan Mikroanatomi pada Gonad Ikan Puso (Harpadon nehereus) yang Ditangkap di Perairan Ujung Pangkah dan Perairan Weru, Jawa Timur
}

\section{Macroscopical and Microscopical Analysis on the Gonad of Bombay Duck Fish (Harpadon nehereus) Caught in Ujung Pangkah and Weru Waters, East Java}

\author{
Merdeka Agus Saputra ${ }^{1}$, Laksmi Sulmartiwi ${ }^{2}$ and Rr. Juni Triastuti ${ }^{2}$ \\ ${ }^{1}$ Program Studi Budidaya Perairan, Fakultas Perikanan dan Kelautan, Universitas Airlangga, Surabaya \\ ${ }^{2}$ Departemen Kelautan, Fakultas Perikanan dan Kelautan, Universitas Airlangga, Surabaya \\ *merdeka-a-11@fpk.unair.ac.id
}

Survei langsung yang dilakukan pada bulan September menunjukkan bahwa ikan puso merupakan salah satu ikan yang menjadi hasil tangkapan di Perairan Ujung Pangkah dan Perairan Weru. Larangan penangkapan ikan di breeding ground (daerah memijah) dan spawning ground (daerah bertelur) merupakan upaya untuk mencegah terjadinya penangkapan berlebihan (over exploitation). Berdasarkan hal tersebut perlu dilakukannya studi aspek reproduksi ikan puso secara makroanatomi dan mikroanatomi agar dapat dijadikan sebagai dasar untuk mengelola dan mengembangkan ikan puso, sehingga ikan tersebut dapat dipertahankan keberadaanya. Penelitian ini bertujuan untuk mengetahui aspek reproduksi dan tahap perkembangan gonad ikan puso secara makroanatomi dan mikroanatomi pada Perairan Ujung Pangkah dan Perairan Weru. Metode penelitian yang digunakan yaitu metode deskriptif, pada penelitian dibuat deskripsi tentang aspek reproduksi pada gonad ikan puso secara makroanatomi dan mikroanatomi. Berdasarkan hasil penelitian menunjukkan bahwa aspek reproduksi pada gonad ikan puso dari Perairan Ujung Pangkah dan Perairan Weru secara makroanatomi dan mikroanatomi meliputi tahap maturing terjadi pada pada kisaran panjang 28,6-31 cm, tahap mature terjadi pada kisaran panjang 26,1-27,2 cm dan tahap resting terjadi pada panjang $30,5 \mathrm{~cm}$. Tahap perkembangan gonad ikan puso secara makroanatomi pada Perairan Ujung Pangkah dan Perairan Weru meliputi TKG I, TKG II menuju TKG III dan TKG III, sedangkan tahap perkembangan gonad ikan puso secara mikroanatomi pada Perairan Ujung Pangkah dan Perairan Weru meliputi tahap TKG II, TKG III dan TKG V.

Kata kunci: Ikan puso, makroanatomi, mikroanatomi, TKG

\begin{abstract}
The direct surveillance conducted in month of September indicated that bombay duck fish is one of the fish catch yields in Ujung Pangkah and Weru Waters. The prohibition regulation of catching fish in breeding ground and spawning ground is the effort to prevent fish from over-exploitation. Therefore, it requires a research about reproduction aspects study of the bombay duck fish in macroscopical and microscopical way in order to obtain information stood for exploring and developing the bombay duck fish so as the fish can keep sustainable. This research is aimed to identify the reproduction aspects and the development stage of bombay duck fish gonad in macroscopical and microscopical way in Ujung Pangkah and Weru Waters. The research method applied was descriptive method by obtaining the data regarding reproduction aspects of bombay duck fish in macroscopical and microscopical way. As the result, the research showed that the reproduction aspects of bombay duck fish including maturing stage in the range of length between $28,6 \mathrm{~cm}$, mature stage in the range of length between $26,1-27,2 \mathrm{~cm}$ and the resting stage occured $30,5 \mathrm{~cm}$. The development of bombay duck fish gonad in macroscopical way in Ujung Pangkah and Weru Waters includes first maturity rate, second maturity rate to third maturity rate and third maturity rate. In contrast, The development of bombay duck fish gonad in microscopical way in Ujung Pangkah and Weru Waters includes second maturity rate, third maturity rate and fifth maturity rate.
\end{abstract}

Key words: Bombay duck fish, macroscopical, microscopical, maturity rate 


\section{Pendahuluan}

Potensi penangkapan ikan puso di Indonesia mengalami penurunan dari 807 ton menjadi 44 ton (Direktorat Pengembangan Daerah BPKM, 2009 dalam Nugroho dkk., 2014). Hal ini terjadi karena populasi ikan puso cenderung menurun, sedangkan jumlah alat tangkap meningkat (Budiman, 2006). Adanya larangan penangkapan ikan di daerah breeding ground (daerah memijah) dan spawning ground (daerah bertelur) merupakan upaya untuk mencegah terjadinya penangkapan berlebihan (over exploitation) (Peraturan Menteri Perikanan dan Kelautan, 2014).

Hal ini menunjukkan perlu adanya informasi reproduksi ikan puso di alam sehingga diketahui spawning ground dan breeding ground dari ikan tersebut. Zamidi et al. (2012) juga menambahkan bahwa studi aspek reproduksi pada ikan dapat memberikan informasi tentang status reproduksi ikan yang diteliti seperti fekunditas, fraksi pemijahan, ukuran ikan selama masa kematangan gonad, pemijahan harian dan periode reproduksi musiman.

Studi aspek reproduksi ikan dapat dilakukan dengan pengamatan secara makroanatomi (macroscopic analysis) dan mikroanatomi (microscopic analysis) (Dorostghoal et al., 2009). Berdasarkan hal tersebut, penelitian bertujuan untuk mengetahui aspek dan tahap perkembangan reproduksi ikan puso secara makroanatomi dan mikroanatomi pada gonad ikan puso. Penelitian ini diharapkan dapat melengkapi informasi tentang aspek reproduksi ikan puso yang dapat digunakan sebagai dasar untuk mengelola dan mengembangkan ikan puso, sehingga ikan ini dapat dipertahankan keberadaannya.

\section{Materi dan Metode}

\section{Alat dan Bahan}

Bahan yang digunakan untuk mendukung penelitian ini, yaitu bahan yang diteliti berupa ikan puso (Harpodon nehereus), bahan pendukung penelitian seperti es batu, aquades, formalin $96 \%$, minyak imersi, dissolved oxygen (DO) kit dan ammonia kit, bahan yang digunakan dalam pembuatan preparat histologi seperti alkohol, parafin, larutan Xilol, larutan Hematoxylin dan Eosin. Peralatan yang digunakan dalam penelitian ini adalah kapal, jaring gill net dengan mata jaring 2,5 inci, Global Positioning System (GPS), cool box, freezer, alat-alat bedah, penggaris, timbangan digital, $\mathrm{pH}$ pen dan termometer serta mikroskop.

\section{Metode Penelitian}

Penelitian ini menggunakan metode deskriptif. Menurut Nazir (2011), metode 
deskriptif adalah suatu metode dalam meneliti status sekelompok manusia, suatu objek, suatu set kondisi, suatu sistem pemikiran, ataupun, suatu kelas peristiwa pada saat sekarang. Pada penelitian dibuat deskripsi tentang aspek reproduksi pada gonad ikan puso secara makroanatomi dan mikroanatomi.

\section{Prosedur Penelitian}

\section{Penentuan stasiun penangkapan ikan}

Penentuan stasiun penangkapan ikan berdasarkan fishing ground ikan puso yang informasinya diperoleh dari nelayan Perairan Weru dan Ujung Pangkah. Fishing ground ikan puso yang didapatkan kemudian dibagi menjadi dua stasiun penangkapan. Pengambilan titik koordinat menggunakan GPS juga dilakukan pada proses penangkapan. Hal ini dilakukan untuk mengetahui titik koordinat dari setiap stasiun penangkapan ikan.

\section{Pengambilan Sampel}

Pengambilan sampel dilakukan dengan teknik sampling insidental. Menurut Sugiono (2006), sampling insidental adalah teknik penentuan sampel secara insidental atau kebetulan yang mana objek penelitian yang ditemukan oleh peneliti dapat dijadikan sebagai sampel penelitian bila objek tersebut dipandang dapat dijadikan sumber data. Jumlah sampel ikan yang digunakan berdasarkan pada jumlah ikan yang secara insidental tertangkap pada lima stasiun di Perairan Weru dan Perairan Ujung Pangkah. Penangkapan ikan dilakukan dengan menggunakan jaring gill net yang disebar pada masing-masing stasiun.

Sampel ikan yang didapatkan dimasukkan ke dalam cool box dan ditimbun dengan es batu yang telah dihancurkan. Sampel ikan tersebut kemudian dibawa ke Laboratorium Pendidikan, Fakultas Perikanan dan Kelautan. Setelah itu, sampel ikan dimasukan ke dalam freezer (pembeku) agar ikan terhindar dari kebusukan. Sampel ikan disimpan pada freezer hingga tahap identifikasi dilakukan.

\section{Pengukuran panjang, berat dan identifikasi}

Ikan puso pada freezer diambil kemudian di-thawing. Ikan puso yang telah dithawing, kemudian diukur berat dan panjangnya untuk diidentifikasi. Panjang ikan puso yang diukur yaitu total length (TL), standard length (SL) dan fork length (FL). Identifikasi juga dilakukan dengan cara penghitungan rumus sirip dorsal, pectoral, anal, dan ventral, serta pengukuran beberapa bagian tubuh lainnya. Pengukuran dan perhitungan tersebut mengacu pada pedoman kunci identifikasi ikan Saanin (1984). 


\section{Pengamatan gonad}

Ikan puso yang telah diidentifikasi kemudian dilakukan pembedahan dengan alat bedah untuk diambil gonadnya. Sampel gonad yang didapatkan kemudian diamati secara makroanatomi dan dibuat preparat histologi untuk diamati secara mikroanatomi.

\section{Analisa Data}

Data yang didapatkan dari pengamatan gonad secara makroanatomi dan mikroanatomi dianalisis secara deskriptif. Semua data yang telah dianalisis secara deskriptif kemudian digunakan untuk menjawab rumusan masalah penelitian.

\section{Hasil dan Pembahasan \\ Tipe Gonad Ikan Puso}

Gonad ikan puso merupakan tipe gonad gonokhorisme terdiferensiasi. Hal ini dapat dilihat dari morfologi gonad. Ciri morfologi gonad ikan puso yang ditemukan yaitu gonad berbentuk seperti ovarium. Warna gonad putih keruh pada bagian anterior, kemerahan pada bagian medial dan merah tua pada bagian posterior dikarenakan adanya kapiler darah. Posisi gonad dan hasil pengamatan secara makroanatomi dapat dilihat pada Gambar 1 dan 2.

Pengamatan secara mikroanatomi menunjukkan dalam satu gonad memiliki dua perkembangan sel kelamin yaitu sel spermatid dan oosit. Perkembangan sel spermatid dan oosit ini diketahui sebagai salah satu ciri dari tipe gonad terdiferensiasi. Hasil pengamatan mikroanatomi dapat dilihat pada Gambar 3.

Tingkat kematangan gonad ikan puso yang ditangkap di Perairan Ujung Pangkah dan Perairan Weru, secara makroanatomi menunjukkan tahap immature, maturing menuju mature, mature dan mature menuju retsing. Tahap immature berupa gonad berwarna putih keruh, tidak ditemukan kapiler darah dan dinding tipis. Hal ini sesuai dengan pernyataan Dorosthgoal et al. (2009) yang menyatakan bahwa gonad terlihat transparan selama tahap immature.

Tahap maturing menuju mature pada pengamatan makroanatomi pada ikan puso yang diperoleh dari Perairan Ujung Pangkah dan Weru memiliki ciri-ciri berupa setengah bagian gonad berwarna putih keruh (opaque) dan kemerahan, setengah bagiannya lagi berwarna merah tua dikarenakan banyaknya jumlah kapiler darah yang berwarna merah pada bagian tersebut, gonad mengisi seluruh rongga tubuh dan berat gonad berkisar 5,27-5,62 gram. Hal ini sesuai dengan penelitian Liao et al. (2013) pada tahap maturing ikan Harpadon microchir secara makroanatomi yaitu ditemukan ada- 
nya kapiler darah pada gonad dengan berat gonad 0,2 sampai 16,8 gram, sedangkan tahap mature, berat gonad lebih dari 16,8 gram dan berwarna putih kekuningan.

Tahap mature pada pengamatan gonad ikan puso secara makroanatomi yang diperoleh dari Perairan Ujung Pangkah dan Weru memiliki ciri-ciri berupa kapiler darah pada seluruh bagian gonad dan dinding gonad tebal (tidak transparan). Keberadaan kapiler darah pada gonad ikan puso dalam tahap mature, juga ditemukan pada ikan $P$. volitan yang memiliki tipe gonad gono- khorisme dalam tahap developing gonad (Priyadharsani et al., 2013).

Tahap resting pada gonad ikan puso pada ikan puso yang diperoleh dari Perairan Ujung Pangkah dan Weru memiliki ciri-ciri berupa bagian posterior gonad terdapat kapiler darah berwarna keunguan dengan bagian ventral gonad berwarna putih keruh. Hal ini sesuai dengan pernyataan Murua et al. (2003) yang menyatakan bahwa tahap resting pada ikan laut umumnya terlihat gonad berwarna keunguan dan masih terdapat oosit.

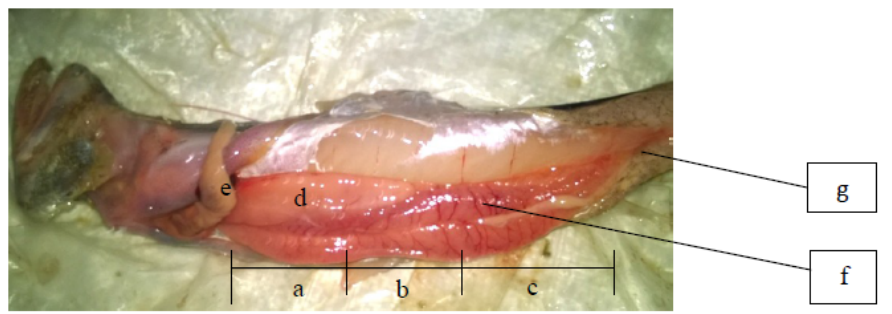

Gambar 1. Posisi gonad pada tubuh ikan puso; (a) bagian anterior gonad, (b) bagian medial gonad, (c) bagian posterior, (d) warna gonad putih keruh, (e) esofagus, (f) kapiler darah dan (g) anus.

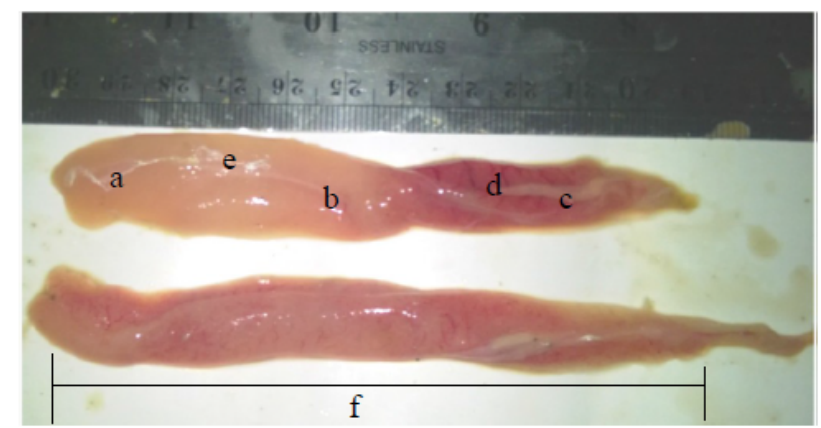

Gambar 2. Hasil pengamatan secara makroanatomi gonad ikan puso; (a) bagian anterior gonad, (b) bagian medial gonad, (c) bagian posterior gonad, (d) kapiler darah pada posterior, (e) bagian gonad yang masih berwarna putih keruh, (f) sampel gonad berwarna merah keunguan dikarenakan kapiler darah yang menyebar 


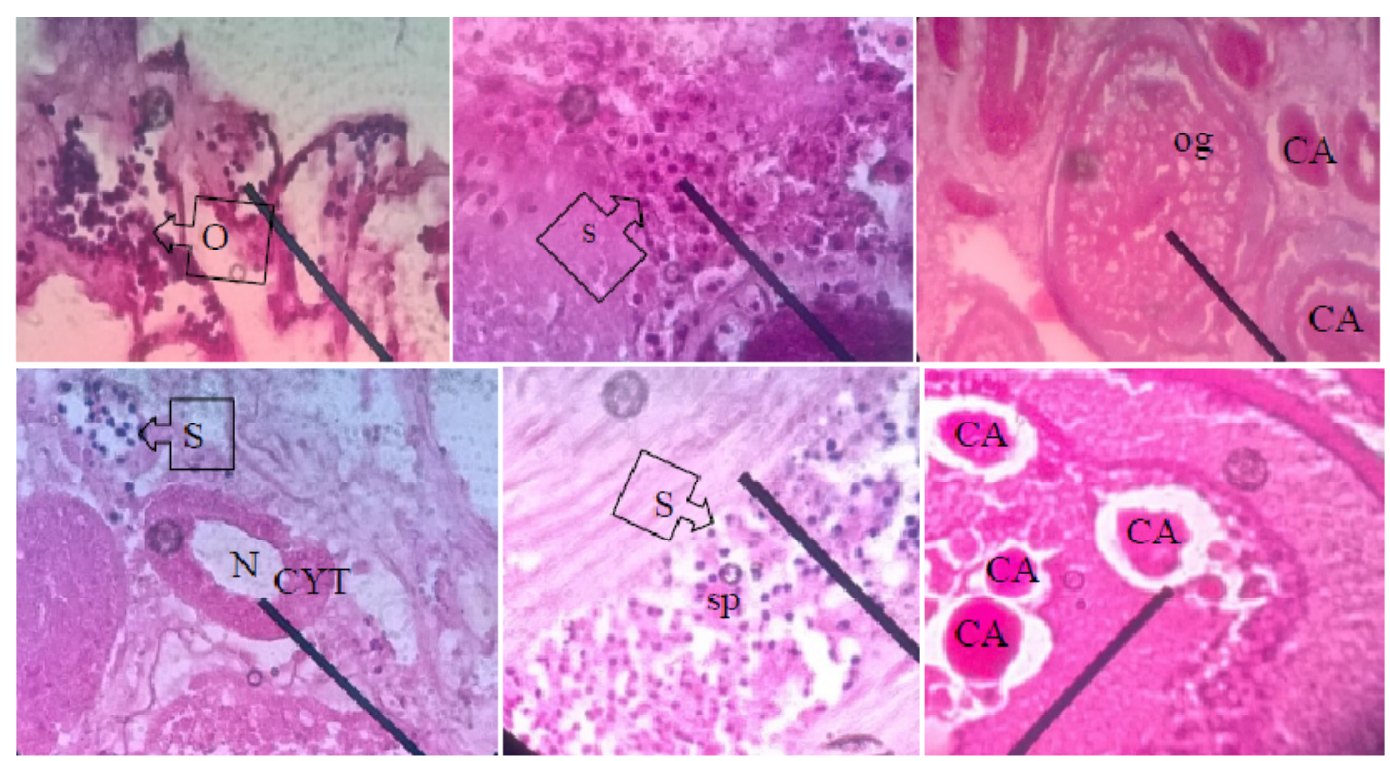

Gambar 2. Pengamatan secara mikroanatomi gonad ikan puso; (CYT) sitoplasma, (N) nukleus, (S) spermatid, (sp) spermatogonium, (CA) corticle alveoli, (O) oosit vitelogenik, (og) oogenium dan (F) folicle.

\section{Hasil Pengamatan Makroanatomi dan}

\section{Mikroanatomi}

Berdasarkan pengamatan secara

Makroanatomi pada ikan puso diperoleh yang diperoleh dari Perairan Ujung Pangkah menunjukkan empat tingkat kematangan gonad yaitu tahap immature, tahap maturing menuju tahap mature, tahap mature dan tahap mature menuju tahap resting. Sedangkan, tingkat kematangan gonad dari ikan puso pada Perairan Weru yaitu maturing menuju mature dan mature. Hasil pengamatan makroanatomi dapat dilihat pada Tabel 1.

Tabel 1. Hasil pengamatan secara makroanatomi pada gonad ikan puso dari Perairan Ujung Pangkah dan Perairan Weru

\begin{tabular}{ccccccccccc}
\hline Variabel & \multicolumn{4}{c}{ Perairan Ujung Pangkah } & \multicolumn{5}{c}{ Perairan Weru } \\
\cline { 2 - 11 } Pengamatan & I & II & III & IV & V & I & II & III & IV & V \\
\hline $\begin{array}{c}\text { Panjang ikan } \\
(\mathrm{cm})\end{array}$ & 30,5 & 28,6 & 27,2 & 25,9 & 25,5 & 31 & 29,9 & 27 & 26,1 & 24,5 \\
$\begin{array}{c}\text { Berat ikan } \\
\text { (gram) }\end{array}$ & 140 & 190 & 100 & 90 & 220 & 130 & 110 & 100 & 80 & 90 \\
$\begin{array}{c}\text { Berat Gonad } \\
\text { (gram) }\end{array}$ & 3,69 & 5,27 & 3,56 & 3,78 & $*$ & 5,62 & $*$ & $*$ & 1,91 & $*$ \\
$\begin{array}{c}\text { Tingkat } \\
\text { Kematangan } \\
\text { Gonad }\end{array}$ & $\begin{array}{c}\text { mature } \\
\text { menuju } \\
\text { resting }\end{array}$ & $\begin{array}{c}\text { maturing } \\
\text { menuju } \\
\text { mature }\end{array}$ & mature & immature & $*$ & $\begin{array}{c}\text { maturing } \\
\text { menuju } \\
\text { mature }\end{array}$ & $*$ & $*$ & mature & $*$ \\
\hline
\end{tabular}


Tingkat kematangan gonad secara mikroanatomi pada ikan puso yang diperoleh dari Perairan Ujung Pangkah yaitu tahap mature, tahap maturing dan tahap resting, sedangkan tingkat kematangan gonad ikan puso yang diperoleh dari Perairan Weru yaitu tahap maturing dan mature. Hasil pengamatan mikroanatomi dapat dilihat pada Tabel 2.

Tingkat kematangan gonad ikan puso secara mikroanatomi yang diperoleh dari Perairan Ujung Pangkah dan Weru menunjukkan tahap resting, maturing dan mature. Tahap maturing ditunjukkan oleh adanya sejumlah oogenium dan oosit tahap corticle alveoli. Menurut Dorostgoal et al. (2009), oosit pada tahap corticle alveoli ditandai dengan adanya yolk globule protein yang terwarnai oleh eosin (merah muda). Koch et al. (2008) menjelaskan juga bahwa fase perkembangan corticle alveoli terjadi karena struktur granularnya pada sitoplasma. Hal ini dikarenakan oleh oosit pada tahap corticle alveoli masih berpoliferasi, sehingga ukuran folikel meningkat dan oosit menjadi berwarna keruh pada suatu area yang dikelilingi oleh nukleus.

Tahap mature pada gonad ikan puso secara mikroanatomi yang diperoleh dari Perairan Ujung Pangkah dan Weru memiliki ciri-ciri, yaitu terdapat oogenium, oosit pada tahap vitellogenic, spermatid dan oosit pada tahap corticle alveoli. Mahmoud (2009) menjelaskan bahwa kumpulan oogenia (oogenium) merupakan germ cell (sel kelamin) tanpa adanya membran, ditemukan soliter dan ada juga dalam bentuk bergerombol, sedangkan oosit tahap corticle alveoli merupakan endapan senyawa trofik (yolk dan lemak). Koch et al. (2008), menambahkan juga bahwa oosit pada tahap vitellogenic terjadi karena adanya peningkatan jumlah dan ukuran yolk vesicle, hal ini dapat dilihat dari peningkatan granula protein dan akumulasi lemak.

Tahap resting pada gonad ikan puso secara mikroanatomi yang diperoleh dari Perairan Ujung Pangkah dan Weru memiliki ciri-ciri, yaitu adanya spermatid, oosit dan hidrasi oosit. Skoblina (2009) menjelaskan juga bahwa proses hidrasi oosit ditandai oleh pembenukan yolk globule protein yang dipengaruhi oleh enzim lisosom proteolitik yang biasanya ditandai dengan germinal vesicle breakdown (GVBD). Hal ini didukung juga oleh pernyataan Dorostgoal et al. (2009) yang menyatakan bahwa pada tahap hidrasi oosit ditandai adanya yolk globule yang mengisi seluruh sitoplasma dan nukleus bergerak menuju kutub animal. Tsai et al. (2011) menambahkan juga bahwa perkembangan spermatosit ditemukan pada tahap 
kematangan gonad ikan yang bertipe gono-

khorisme.

Tabel 2. Hasil pengamatan secara mikroanatomi pada gonad ikan puso dari Perairan Ujung Pangkah dan Perairan Weru

\begin{tabular}{|c|c|c|c|c|c|c|c|c|c|c|}
\hline \multirow{2}{*}{$\begin{array}{c}\text { Variabel } \\
\text { pengamatan }\end{array}$} & \multicolumn{5}{|c|}{ Perairan Ujung Pangkah } & \multicolumn{5}{|c|}{ Perairan Weru } \\
\hline & I & II & III & IV & $\mathrm{V}$ & $\mathrm{I}$ & II & III & IV & $\mathrm{V}$ \\
\hline Tahap & resting & maturing & mature & mature & $*$ & maturing & $*$ & $*$ & mature & $*$ \\
\hline Oogenium & - & - & - & - & $*$ & - & $*$ & $*$ & $\sqrt{ }$ & $*$ \\
\hline $\begin{array}{l}\text { Oosit } \\
\text { vitelogenic }\end{array}$ & - & - & $\sqrt{ }$ & $\sqrt{ }$ & - & - & - & - & $\sqrt{ }$ & $*$ \\
\hline Spermatid & $\sqrt{ }$ & - & $\sqrt{ }$ & $\sqrt{ }$ & $*$ & - & $*$ & $*$ & $\sqrt{ }$ & $*$ \\
\hline Oosit & $\sqrt{ }$ & $\sqrt{ }$ & - & $\sqrt{ }$ & $*$ & $\sqrt{ }$ & $*$ & $*$ & $\sqrt{ }$ & $*$ \\
\hline Corticle alveoli & - & $\sqrt{ }$ & - & $\sqrt{ }$ & $*$ & $\sqrt{ }$ & $*$ & $*$ & $\sqrt{ }$ & $*$ \\
\hline Hidrasi oosit & $\sqrt{ }$ & - & - & - & $*$ & - & $*$ & $*$ & - & $*$ \\
\hline
\end{tabular}

Menurut Peterson and Wayanski (2003), spermatocyst yang mengandung spermatosit dan spermatid termasuk ke dalam tahap late developing. Berdasarkan hasil penelitian pada ikan puso yang ditangkap di Perairan Ujung Pangkah dan Weru menunjukkan bahwa pada ikan puso dengan tahap resting dan tahap mature ditemukan adanya spermatid yang bergerombol pada gonad. Hal ini menunjukkan bahwa pada tahap mature dan tahap resting yang berkembang pada gonad, juga sedang terjadi tahap perkembangan late developing yang merupakan salah satu tahap perkembangan testis pada gonad yang bertipe gonokhorisme.

Berdasarkan hasil pengamatan secara makroanatomi pada ikan puso yang diperoleh dari Perairan Ujung Pangkah dan Weru memiliki, tingkat kematangan gonad terjadi secara bervariasi, yaitu pada tahap resting terjadi dengan panjang ikan puso $30,5 \mathrm{~cm}$, tahap mature terjadi dengan panjang ikan puso 28,6 $\mathrm{cm}$ dan $31 \mathrm{~cm}$, tahap maturing terjadi dengan panjang ikan puso $26,1 \mathrm{~cm}$ dan $27,2 \mathrm{~cm}$. Hal ini sesuai dengan Penelitian Ghosh et al. (2009) menunjukkan bahwa gonad ikan puso di Perairan Surastra India mencapai kematangan gonad pada tahun pertama dengan ukuran panjang 20,2 cm pada umur 11,5 bulan. Rata-rata panjang ikan puso untuk mencapai kematangan gonad ditemukan pada ukuran panjang $23 \mathrm{~cm}$ (Pillai and Menon, 2000).

\section{Kesimpulan dan Saran}

Aspek reproduksi ikan puso dari Perairan Ujung Pangkah dan Perairan Weru pada bulan September dan Oktober secara makroanatomi dan mikroanatomi meliputi tahap maturing terjadi pada kisaran panjang 
28,6-31 cm, tahap mature terjadi pada kisaran panjang 26,1-27,2 $\mathrm{cm}$ dan tahap resting terjadi pada panjang $30,5 \mathrm{~cm}$. Tahap perkembangan gonad ikan puso pada bulan September dan Oktober secara makroanatomi pada Perairan Ujung Pangkah dan Perairan Weru meliputi TKG I, TKG II menuju TKG III dan TKG III, sedangkan tahap perkembangan ikan puso secara mikroanatomi pada Perairan Ujung Pangkah dan Perairan Weru meliputi tahap TKG II, TKG III dan TKG V. Berdasarkan seluruh rangkaian penelitian dan pembahasan maka disaran bahwa perlu adanya dilakukan penelitian tentang tahap perkembangan gonad ikan puso pada bulan September dan Oktober di Perairan Ujung Pangkah dan Perairan Weru. Selain itu, perlu dilakukan penelitian tentang faktor lingkungan yang berpengaruh pada reproduksi ikan puso di Perairan Ujung Pangkah dan Perairan Weru.

\section{Daftar Pustaka}

Budiman, 2006. Analisis Sebaran Ikan Demersal Sebagai Basis Pengelolaan Sumberdaya Pesisir di Kabupaten Kendal. Thesis. Universitas Diponegoro. 144 hal.

Dorostghoal, M., Peyghan, R., Papan, F. and Khalili L. 2009. Macroscopic and Microscopic Studies of Annual Ovarian Maturation Cycle of Shirbot Barbus grypus in Karoon River of Iran. 10 (2) : 27.
Effendi, I. M. 1997. Biologi Perikanan. Penerbit : Yayasan Pustaka Nusatama. hal. 3-21.

Ghosh, S., Pillai, N.G.K. and Dhokia, H. K. 2009. Fishery and Population Dynamics of Harpadon nehereus (Ham) off Saurashtra Coast. Indian Journal of Fish. 56 (1) : 13-19.

Ghosh, S. 2014. Fishery, Reproduction Biology and Diet Characteristic of Bombay Duck Harpadon nehereus from the Saurashtra Coast. Indian Journal of Marine Sciences. 43 (3) : 418-426.

Liao, Y.Y., Luo, S.R. and Liu, K.M. 2013. Reproductive Biology of the Bombay-Duck Harpadon microchir in the Coastal Waters off Soutwestern Taiwan. Journal of Marine Sciene and Technology. 013-1211-1.

Mahmoud, H.H. 2009. Gonadal Maturation and Histological Observation of Epinephelus areolatus dan Lethrinus nebulosus in Halaieb/Shalatien Area "Red Sea", Egypt. Global Veterinaria. 3 (5) : 414-423.

Nazir, M. 2011. Metode Penelitian. Penerbit Ghalia Indonesia. Bogor. hal 57.

Nugroho, D.E, Ibrahim dan Rahayu, A.D. 2014. Variasi Morfologi dan Kekerabatan Ikan Nomei Perairan Kalimantan sebagai Upaya Konservasi Ikan Laut Lokal di Indonesia. Seminar Nasional XI Pendidikan Biologi FKIP UNS. 505-511.

Peterson, B.N.J., and Wyanski. 2014. A Propose "Straw Man" Reproductive Classification for Male Teleost. Article of Dept. Coastal Science and Marine Resource Research Institute. pp. 10.

Pillai, V.N. and Menon, N.G. 2000. Marine Fisheries and Management. Central Marine Fisheries Research Institute (Indian Council of Agricultural Research). 349-353. 
Priyadharsini, S., Manoharan, J., Varadharajan, D. and Subramaniyah, A. 2013. Reproductive Biology and Histology Study of Red Lionfish Pterois Volitan from Cuddalore, South East Coast of India. Journal Aquac Res Development. 4:6.

Saanin, H. 1984. Taksonomi dan Kunci Identifikasi Ikan. Edisi pertama. Jakarta. hal. 225-226.

Skoblina, M.N. 2010. Hydration of Oocytes in Teleost Fishes. Russian Journal of Developmental Biology. 41 (1) : 112.

Tsai, Y.J., Lee, M.F, Chen, C.Y., and
Chang, C.F. 2011. Development of Gonadal Tissue and Aromatase Function in the Protogynus OrangeSpotted Grouper Epinephelus coioides. Zoological Studies. 50 (6): 693-704.

Zamidi, S., A., Zaidi, C.C., Mazlan, A.G, Alam, G. M., Al-Amin, A.Q, and Simon, K.D. 2012. Fecundity and Temporal Reproductive Cycle of Four Finger Threadfin (Eleutheronema tetradactylum) in Malaysian Coastal Water. Asian Journal of Animal and Veterinary Advances. 7 (11) : 1100-1109. 